\title{
Communicative Taboos in Modern Business Etiquette
}

\author{
Kanyukova Irina Yanovna, \\ Candidate of Pedagogical Sciences, Associate Professor of the Department \\ of Philosophy and Pedagogy, Kiev National University of Culture and Arts, \\ Kiev, Ukraine,
}

\author{
Sidorovskaya Evgeniya Andreevna, \\ Candidate of Cultural Studies, Senior Lecturer of the Department \\ of Philosophy and Pedagogy, Kiev National University of Culture and Arts, \\ Kiev, Ukraine
}

The article examines the features of communicative taboos in business etiquette.

The taboo system has protected core values for centuries and has been an unwritten social code. Taboo reflects the foundations of morality, spiritual culture, features of thinking and worldview of individuals and ethnocultural communities. The spheres and nature of taboos are a reflection of the times and cultures of the people and are clearly manifested in the process of intercultural communication. Violation of the most severe taboos can lead to termination of contact.

The study found that in the process of intercultural communication, given the similarity of most taboo topics, the degree of categoricalness of their use is different, or the circumstances under which certain topics can be raised are different.

In order to comply with the verbal rules of business etiquette valid in one's own or in other cultures and ethnic groups and at the same time ideologically express the necessary meaning, promoting friendly intercultural communication, it is necessary to use a number of ways not to break taboos related to language units. etc. In the case of nonverbal taboos, mutual misunderstanding and non-perception in the process of nonverbal communication usually occurs because a somatic object is used to nonverbally express a certain meaning or perform a certain movement, which cannot be used from the point of view of another culture.

Key words: verbal taboos, nonverbal taboos, intercultural communication, business etiquette, taboo topics

Актуальність дослідження. Однією з характерних особливостей міжкультурної комунікації - особливої форми комунікації двох або більше представників різних культур, етносів, процес якої представлений обміном інформації та культурними цінностями взаємодіючих культур, що відображає іiі нормативну природу, є широке поширення різноманітних соціальних обмежень, заборон, які штучно звужують сферу спілкування окремих індивідів та їх груп. Особливе місце займають вони в діловому етикеті - сукупності правил та норм, визнаних загальноприйнятими в діловій сфері та міжнародному економічному співробітництві. 
Зважаючи на посилення загальносвітової відкритості та взаємозалежності країн, регіонів, підприємств та співтовариств - глобалізаційних процесів, актуальним $є$ дослідження проблематики табу в рамках ділового етикету в контексті особливостей міжкультурної комунікації.

Аналіз публікацій. Взаємодія культур на сучасному етапі розвитку наукової думки розглядається у складному динамічному контексті - процеси модернізації в усіх галузях життєдіяльності людини являють собою складний багаторівневий синтез різних підсистем, маркованих відповідними акцентами у системі ціннісних переваг.

Особливу увагу науковців у контексті глобалізаційних процесів привертає питання впливу на сучасну культуру спілкування, взаємодію людей під час міжкультурної комунікації. Серед вітчизняних дослідників окремі аспекти міжнародного ділового етикету висвітлено у наукових публікаціях та розвідках Н. Ботвіна, О. Брух, Н. Завальницької, Ю. Словської, М. Лукачевич, В. Малахова, І. Осечинського, Ю. Палеха, Л. Ручко, В. Снітинського, М. Стахова, С. Цвілюк, С. Федько, I. Хожило, Г. Чайки та ін.

Вивчення феномену «табу» - елемента ділового етикету, тактичної складової культурної компетенції, що передбачає вміння розпізнавати ціннісні установки, ознаки психологічної та соціальної ідентичності, характерні для окремої культури, дозволяє виділити «проблемні» сфери та діагностувати стан духовності суспільств.

Мета статті - виявити особливості комунікативних табу в рамках ділового етикету.

Виклад основного матеріалу. Важливою складовою діалогу культур є знання та дотримання національних культурно-специфічних особливостей. Зазвичай комунікатори спілкуються відповідно до власних національних норм комунікативної поведінки, що, як правило, не повністю відповідають нормам іноземного партнера.

В міжкультурній комунікації табу займають особливе місце, оскільки непорозуміння, що викликані порушенням табу є найбільш відчутними.

Табу - багатопланове явище мови та культури, що включає лінгвокогнітивний, соціокультурний, психологічний, психолінгвістичний, прагмалінгвістичний та лінгвістичний аспекти. 
Термін «табу», що належить до міждисциплінарної термінології і широко використовується в антропології, етнології, соціології, культурології та інших науках має полінезійське походження. Відомий антрополог Т. Норскот стверджує, що табу включає в себе священну (або навпаки, нечисту) ознаку осіб або речей; рід обмежень, заборон, що витікають з цієї ознаки та святість (або тї протилежність - нечистість), що відбувається внаслідок порушення цих заборон [7].

Табу означає заборону, що виникає в сфері суспільного життя на різних рівнях людського розвитку. Початково поняття табу, що з'явилося у багатьох народів на основі міфологічних вірувань [5, с. 104], використовувалося лише для означення особливого роду заборон на певні дії. Проте якщо будь-яке поведінкове табу є забороною, то не будьяка норма поведінки, що забороняє певні дії $\epsilon$ табу, оскільки табу $є$ забороною особливого роду.

Незважаючи на відмінність давнього і сучасного розуміння табу - якщо у первісної людини при дотриманні табу на першому місці стояли страх перед демонічними силами, забобони та упередження, то нині людиною керують такі емоційно-модальні стани як сором, скромність, дотримання заповідей, небажання образити кого-небуть - сенс та детермінуючі ознаки табу лишаються незмінними, а саме, психологічний, соціальний та релігійний фактори його виникнення.

Зі змінами культурних умов сфера використання табу також трансформується, оскільки відкидаючи табу попередніх історичних етапів, сучасне суспільство створює нові табу, а деякі теми табуювання лишаються незмінними.

Термін «табу» на сучасному етапі розвитку суспільства означає порушення правил порядності або етикету.

Вітчизняна дослідниця Ю. Словська, визначає табу як «жорстку заборону або ситуативне обмеження на вживання в мовленні певних мовних одиниць (звуків, букв, лексем, словосполучень тощо), несегментних фонетичних одиниць (тону, висоти голосу, тембру, інтонації тощо), тем, а також уникання спілкування з окремими особами, зумовленого різними екстралінгвістичними чинниками (релігійно-магічними, суспільнополітичними, культурними, морально-етичними тощо» [2, с. 49].

Дослідники наголошують на трьох основних компонентах табу:

- глибока впевненість людей, які належать до певного колективу; 
- відчуття страху перед невідомою небезпекою;

- заборона як норма життя [9, с. 258].

Е. Ліч стверджує, що табу можна віднести до культурних універсальній [4, с. 46]. Оскільки раніше багато явищ та подій здавалися людям незрозумілими, викликаючи відповідно страх та побоювання, вони ухилялися від вимовляння назви певного феномену або предмету - так з'явилися заборонені або табуйовані слова. У багатьох культурах є заборона на вживання назв певних предметів та явищ. Наприклад, імен богів, духів та демонів, смерті, хвороб, тварин, сонця, вогню, місяця та частин людського тіла.

Зазвичай табу поширюється на поводження з культово-значущими предметами $\mathrm{i}$ особами - релігійній забороні у первісних народів підлягали певні дії з метою уникнення ворожих проявів надприродних сил, окрім того існувала заборона на вживання певних слів, зумовлена соціально-політичними, історичними, культурними, етичними та емоційними факторами.

Наприклад, у китайській культурі типовим є табу на вимову або написання імен пращурів та імператорів - у Китаї з давніх давен вважалося актом прояву глибокої неповаги вимовити ім'я поважної та старшої людини, особливо імператора та власного батька.

У даному дослідженні поняття табу розуміємо як соиіально та культурно зумовлена заборона вимовляти ті або інші слова та вирази, а також заборона здійснювати певні регламентовані культурою та суспільством дії.

На думку дослідників, зазвичай табу викликані невідповідністю між біологічним станом людини та його біологічними характеристиками з одного боку і культурним або соціальним статусами людини, з іншого. Вони виникають внаслідок протиріччя між відносною свободою тілесної, мовної, акціональної та іншої поведінки людини та регламентаціями, що накладаються на іiі поведінку соціальним колективом або культурою [3, с. 6].

Комунікативні табу в контексті специфіки ділового етикету можемо типологізувати наступним чином:

- вербальні табу: заборона на використання грубих або нецензурних виразів, а також недоречних у тій чи іншій комунікативній ситуації мовних формул, що використовуються без урахування статусно-рольових стосунків між комунікантами; 
- невербальні табу (заборона конкретної жестикулящії, міміки, поз): заборона використання окремих компонентів невербальної поведінки під час спілкування (наприклад, не можна відвертатися від співрозмовника, пильно дивитися в очі, сильно жестикулювати, багаторазово торкатися до співрозмовника, голосно розмовляти, говорити швидко, тримати руки в кишенях тощо);

- тематичні табу: заборона обговорення певних тем, що вважаються принципово конфліктними та етично недоречними (табуйовані теми $є$ динамічним, соціально залежним поняттям, оскільки в умовах внутрішньокультурної комунікації певні теми можуть припинити вважатися табу, а інші - навпаки табуюватися).

На думку дослідників, саме недотримання тематичних табу $є$ найбільш небезпечним для комунікативних взаємодій, оскільки це може викликати непередбачувану емоційну реакцію або суспільний докір [9, с. 239].

Хоча існують й інші типологізації. Наприклад, Г. Крейдлін розрізняє вербальні, невербальні та змімані, або вербально-невербальні комунікативні табу. До останнього типу дослідник відносить заборону вимовляти певні слова і одночасно виконувати ті чи інші знакові дії в актах комунікації [3, с. 6]. На думку науковця, у кожній галузі функціонування табу доцільно виділити такі відгалуження, як контекстно (ситуативно) незалежну та контекстно (ситуативно) зумовлену.

Поняття табуйованості знаходиться в морально-етичній площині суспільної свідомості, відповідно у зв'язку з цим класифікація тем на припустимі і неприпустимі також має морально-етичний характер, що сформувався під впливом суспільної думки за принципом комунікативної доречності або недоречності.

Серед основних сфер функціонування вербальних табу виділяється релігія, моральна сфера та політика, а також суспільна та міжособистісна поведінка людей, ритуальна та церемоніальна галузь (в середині кожної виокремлюють особливо табуйовані теми та предмети).

Так, наприклад, найпоширенішими тематичними табу для європейців є:

- обговорення теми смерті;

- обговорення інтимних стосунків;

- обговорення расової, національної, гендерної, релігійної приналежності; 
- обговорення негативних явищ дійсності (безробіття, проституція, злидні, алкоголізм, наркоманія, збройні конфлікти та ін.);

- обговорення захворювань; обговорення дискусійних тем з точки зору моралі, етики та права (аборти, сурогатне материнство, евтаназія, клонування та ін.);

- недоречні питання особистого характеру.

Окрім того, у Великобританії не прийнято обговорювати особисте життя, погані звички та захворювання, публічно говорити про фізіологічні процеси організму. Забороненими темами вважаються також питання про заробітню платню, сімейний стан та вік, тобто табуйованими $є$ такі теми, які так чи інакше могли б викликати незадоволення або непорозуміння з боку співрозмовника, призвести до суперечок або чвар.

Евфемізм як один із різновидів стилістичних засобів дозволяє співрозмовникам варіювати мови в залежності від комунікативних умов, за необхідністю приховувати або варіювати власні наміри, з метою уникнення конфліктів у спілкуванні, які можуть відбуватися у випадку прямолінійної номінації певних дій, предметів та ін., тобто у випадку порушення табу.

Табу та евфемізми підтримують відповідний культурний рівень вербального спілкування та етичні норми мовної поведінки.

Дослідники наголошують на відмінностях невербальних табу в культурах апофатичного ставлення, суть якого полягає в прагненні людини приховати тіло від сторонніх очей, зробивши його непомітним, непримітним і разом із тим, ідеальним, та культурах вільної тілесної поведінки, водночас акцентуючи на важливості контексту, оскільки невербальні знакові дії можуть бути табуйованими або нетабуйованими в залежності від значень, які вони виражають [3, с. 8].

Наприклад, підморгування табуйовано в апофатичних культурах у контексті флірту і дозволено в культурах вільної тілесної поведінки, хоча у випадку використання даного жесту як натяку на «співучасть в таємній події» дозволено в обох культурах.

Для жестових табу важливу роль відіграє розподіл, що стосуються до самих тілесних об’єктів, табуйованих у конкретній культурі у ситуації, що передбачає виконання певного жесту або певного незнакового руху. Зокрема, деякі табуйовані 
тілесні об'єкти в іншій культурі позиціонуються як повноправні компоненти фізичної реалізації жесту або руху такої ж форми.

Взаємне непорозуміння та несприйняття в процесі невербальної комунікації зазвичай виникає тому, що для невербального вираження певного сенсу або виконання певного руху використовується соматичний об'єкт, яким з точки зору іншої культури користуватися не можна.

Наприклад, у процесі спілкування з людиною мусульманської культури, а також деяких інших культур, не можна використовувати ліву руку, оскільки у них вона вважається нечистою (в культурі мусульман для всього брудного, що вимагає використання рук, треба використовувати саме ліву руку). У багатьох країнах, у тому числі на Близькому Сході, деяких частинах Індії та Африки (в тому числі Західної Африки) [6, с. 171] табуйованим є використання лівої руки для того, щоб помахати людині на знак привітання, прийняти подарунок або щось передати (навіть якщо порушується принцип фізіологічної зручності).

Відповідно до європейського етикету неприпустимо сидіти, схрестивши ноги, під час розмови з людиною тої культури, в якій ця поза осуджується.

Важливість знання та дотримання табу національних культур у процесі міжкультурного ділового спілкування не применшує важливість дотримання вербальних та невербальних табу загальноприйнятих в масштабах світового ділового етикету, до яких належить:

- табу на прояв ознаки переваги або зневаги до співрозмовника;

- табу на створення психологічних бар'єрів;

- табу на відкриту критику або приниження співрозмовника;

- табу на нетактовні дії стосовно співрозмовника (наприклад, ігнорувати, висловлювати підозри, висміювати, обривати промову та ін.) [1, с. 97];

- табу на тримання рук у кишенях, складання їх на грудях, жест вказівним пальцем та ін.

Система табу протягом століть захищала основні цінності та була неписаним соціальним кодексом. Табу відображає основи моральності, духовної культури, особливості мислення та світосприйняття окремих особистостей та етнокультурні спільноти. Сфери та характер табуювання є відображенням доби та культур народу і 
проявляються в процесі міжкультурного спілкування. Порушення найбільш жорстких табу може призвести до припинення контакту.

Висновки. Дослідження виявило, що в процесі міжкультурної комунікації за умови схожості більшості тем табу, відмінними є ступінь категоричності їх вживання, або ж відрізняються обставини за яких можуть бути підняті ті чи інші теми.

3 метою дотримання чинних у власній або в чужій культурах та етносах вербальних правил ділового етикету і водночас ідеоматичного вираження необхідного сенсу, сприяючи доброзичливому міжкультурному спілкуванню, варто використовувати ряд способів не порушувати табу, пов’язаних з мовними одиницями, зокрема синонімічні перефразування, метафоричні заміни та ін. У випадку з невербальними табу взаємне непорозуміння та несприйняття в процесі невербальної комунікації зазвичай виникає тому, що для невербального вираження певного сенсу або виконання руху використовується соматичний об'єкт, яким з точки зору іншої культури користуватися не можна.

\section{References}

1. Gritsenko, T.B., Ishchenko, T.D., Melnichuk, T.F. (2007). Kyiv: Center for Educational Literature.

2. Yelovskaya, Y. V. (2015). Implementation of taboos in business discourse (on the material of business speech of Ukrainians). Odessa Linguistic Bulletin. Issue 5 (1), pp. 48-51.

3. Kreidlin, G. E. (2018). Non-verbal taboos and mixed communicative taboos in different cultures. Izvestiya RAN. Series of Literature and Language. Vol. 77. no. 4., pp. 5-14.

4. Lich, E. (2001). Culture and communication: The logic of the relationship of symbols. On the use of structural analysis in social anthropology. Moscow: Eastern Literature.

5. Reformatskiy, A. A. (1998). Taboos and euphemisms. Introduction to linguistics. Moscow: Aspect Press.

6. Ameka, F. K., Breedweld, A. (2004). Areal cultural scripts for social interaction in West African communities. Intercultural Pragmatics, Issue 1-2.

7. Britannica. The Editors of Encyclopaedia. "Taboo". Encyclopedia Britannica. URL : https://www.britannica.com/topic/taboo-sociology. Press.

8. Kanazawa, I. (2001). Introduction to Religious Anthropology, Religious Culture

9. Wardhaugh, R. (2006). An Introduction to Sociolinguistics (Fifth edition). Oxford: Blackwell Publishers Ltd. 


\section{Translation of the References to the Author's Language}

\section{Список використаних джерел}

1. Гриценко Т.Б., Іщенко Т.Д., Мельничук Т. Ф. Київ : Центр учбової літератури, 2007. $344 \mathrm{c}$.

2. Словська Ю. В. Реалізація табу в діловому дискурсі (на матеріалі ділового мовлення українців). Одеський лінгвістичний вісник. 2015. Вип. 5(1). С. 48-51.

3. Крейдлин Г. Е. Невербальные табу и смешанные коммуникативные табу в разных культурах. Известия РАН. Серия Литературы и языка. 2018. Т. 77. № 4., С. 5-14.

4. Лич Э. Культура и коммуникация: Логика взаимосвязи символов. К использованию структурного анализа в социальной антропологии. Москва : Восточная литература, 2001. 142 с.

5. Реформатский А.А. Табу и эвфемизмы. Введение в языковедение. Москва : Аспект Пресс, 1998. 536 с.

6. Ameka F.K., Breedweld A. Areal cultural scripts for social interaction in West African communities. Intercultural Pragmatics, 1-2. 2004.

7. Britannica. The Editors of Encyclopaedia. "Taboo". Encyclopedia Britannica. URL : https://www.britannica.com/topic/taboo-sociology (дата звернення : липень 2021). 362 p.

8. Kanazawa I. Introduction to Religious Anthropology, Religious Culture Press, 2001.

9. Wardhaugh R. An Introduction to Sociolinguistics (Fifth edition). Oxford: Blackwell Publishers Ltd, 2006. 418 p. 